\title{
How Policy Shapes Competition: Early Railroad Foundings in Massachusetts
}

\section{Citation}

Dobbin, Frank, and Timothy J. Dowd. 1997. How policy shapes competition: Early railroad foundings in Massachusetts. Administrative Science Quarterly 42(3): 501-529.

\section{Published Version}

http://dx.doi.org/10.2307/2393736

\section{Permanent link}

http://nrs.harvard.edu/urn-3:HUL.InstRepos:3202908

\section{Terms of Use}

This article was downloaded from Harvard University's DASH repository, and is made available under the terms and conditions applicable to Other Posted Material, as set forth at http:// nrs.harvard.edu/urn-3:HUL.InstRepos:dash.current.terms-of-use\#LAA

\section{Share Your Story}

The Harvard community has made this article openly available.

Please share how this access benefits you. Submit a story.

\section{Accessibility}


How Policy Shapes

Competition: Early

Railroad Foundings

in Massachusetts

\section{Frank Dobbin}

Princeton University

Timothy J. Dowd

Emory University
(C) 1997 by Cornell University $0001-8392 / 97 / 4203-0501 / \$ 1.00$

\footnotetext{
We are indebted to the National Science Foundation (grant \#SES90-11005) and Princeton's Committee for Research in the Humanities and Social Sciences for support. Thanks to Tiernan Ray, Wendy Roberts, and Valery Mamedaliev for help with the coding. We thank Terry Boswell, Glenn Carroil. Miguel Centeno, Jody ClayWarner, Paul DiMaggio, Neil Fligstein John Freeman, Mark Granovetter. Heather Haveman. Alex Hicks, Dev Jennings, Matthijs Kalmijn, Ron Jepperson, Frank Lechner. John Meyer. Huggy Rao, German Rodriguez, Richard Rubinson. David Strang, John Sutton, Fatricia Thornton, Daniel Weber, Regina Werum, Bruce Western. Yuval Yonay, Viviana Zelizer Xueguang Zhou, three anonymous ASO reviewers, and Associate Ed tor Mark Mizruchi for suggestions.
}

To examine the effects of policy on markets and competition we outline hypotheses about the effects of three common policy regimes - public capitalization, pro-cartel, and antitrust-on competition and the founding of new firms. Analyses of Massachusetts railroad foundings between 1825 and 1922 show that public capitalization raises the number of foundings by increasing available resources, pro-cartel policies raise the number of foundings by dampening competition from incumbents, and antitrust depresses foundings by stimulating competition. Ecological factors only show the expected effects once policy is controlled. Industrial organization factors show no net effects. We argue that public policy establishes the ground rules of competition and thus creates varieties of market behavior.

What factors influence industry competition in ways that affect the establishment of new firms? Organizational ecologists point to the environmental resources at hand and the level of competition for those resources. Industrial organization economists stress two characteristics of industry structure: concentration and capital accumulation. Business historians and organizational institutionalists point to two characteristics of the policy environment: state capitalization and policies regulating competition. While these three approaches address common outcomes, they are rarely considered together. We consider them together here, by analyzing time-series data on the founding of 317 railroads in Massachusetts between 1825 and 1922. During this period, there was great variation in the six factors of interest: founding resources, number of competitors, industry concentration, capital accumulation, state capitalization, and public policies regulating competition. There was also great variation in the frequency of foundings. Because public policy creates the property rights upon which market exchange is founded, it follows that different policy regimes should produce different varieties of competitive behavior (White, 1988; Zelizer, 1988)

\section{Public Policy and the Construction of Business Strategy}

While we now know a great deal about the effects of population characteristics and industry structure on competition within a stable policy regime, we know little about the effects of different policy regimes. This is surely because much organizational and economic scholarship comes from the United States, where a belief in laissez faire obscures the role of the state in markets and where the size and geographical isolation of the economy render the policies of other nation-states distant and intangible. It may also be a consequence of the fact that national policy styles tend to be consistent over time, making controlled analysis difficult. France has capitalized vital industries since the time of Louis XIV (Shonfield, 1965); Germany has encouraged cartels since the late nineteenth century (Chandler, 1990); and the United States has enforced antitrust since the beginning of the twentieth century (Fligstein, 1990).

Early American railroading provides a natural laboratory for studying the effects of policy on competition, because railroads experienced each of these three policy styles. Be- 
tween 1825 and 1871, American railroads operated under public capitalization policies as generous as France's (Hartz, 1948; Dunlavy, 1993). Between 1872 and 1896, the industry operated under pro-cartel policies as friendly as Germany's (Kolko, 1965; Berk, 1994). From 1897, railroads operated under the antitrust policies that would be used to govern most American industries in the twentieth century. In short, American railroads experienced both public capitalization and exclusively private capitalization, both pro-cartel and antitrust policies (Dobbin, 1994). We expect these policy regimes to shape the two principal factors that population ecologists have found important: resource availability and competition among incumbents. Public capitalization expands the resource pool. Pro-cartel policies dampen competition. Antitrust enlivens competition.

Our aim is to build on neoinstitutional insights about the effects of policy on business practice. Institutionalists have been concerned with the social construction of both human rights and economic rationality (Meyer, 1994; Strang, 1994; Scott, 1995). In early studies tracing the effects of federal policies in such realms as equal employment opportunity, policy shows fairly direct effects, causing firms to adopt specific practices (DiMaggio and Powell, 1983, 1991) or encouraging managers to invent new practices within narrow guidelines (Meyer and Rowan, 1977; Edelman, 1990; Sutton and Dobbin, 1996).

Recent studies suggest that the role public policy plays in shaping economic rationality is sometimes more subtle. In these studies, public policies have been shown to influence corporate behavior by framing the competitive environment, rather than by promoting specific practices. Since Fligstein (1990) explored the role of policy in the construction of such core business strategies as conglomeration, institutional insights have been used to study thrifts' decisions to enter new markets (Haveman, 1994), deconglomeration among large firms (Davis, Diekmann, and Tinsley, 1994), the diffusion of new accounting practices (Mezias, 1990), and the founding of new firms (Baum and Oliver, 1992). We build on this foundation, seeking to identify the key policy characteristics that shape industry competition and thereby influence entrepreneurial decisions.

We argue that most new policies create constraints and incentives, rather than dictating firm behavior, and that managers construct new business strategies taking those constraints and incentives into account (Edelman, 1992; Dobbin et al., 1993; Fligstein, 1996). Managers reach consensus on how to respond to policies largely by observing and imitating peers, as both neoinstitutionalists (Strang and Mever, 1993; Meyer, 1994) and network theorists (White, 1981; Granovetter, 1985) have suggested. Only after managers have reached some sort of consensus are effects of policy on business behavior predictable. Thus, railroad managers defined merger as the appropriate response to the Interstate Commerce (1887) and Sherman Antitrust (1889) acts, but only after a decade of experimenting with various covert forms of collusion. Understanding how managers devise new strategies is key to understanding the effects of policy, and in a companion piece to this (Dowd and Dobbin, 1998) 


\section{Railroad Foundings}

we explore the range of strategies devised after each railroad policy shift and the process of consensus formation. Railroaders were pioneers in more than one sense in American business: the strategies they devised for dealing with pro-cartel and with antitrust policies soon spread to other industries. We expect the results reported below to be generalizable in part because other industries followed the lead of the railroads.

Because policy regimes frame economic behavior, we take issue with Hannan and Carroll's (1995: 540) contention that regulation is of little theoretical interest: "It is hard to think of a relevant theory in any of the social sciences that is inconsistent with the view that regulation directed at an organizational population affects its evolution. Consequently, evidence about such effects has little theoretical import." Public policy creates competition in the first place, by establishing the legal framework for the firm, the monetary system, and the rules of exchange (Roy, 1997). Regulatory regimes can virtually eliminate competition, as when states sponsor cartels, or bring competition to a head, as when states vigorously enforce antitrust. Regimes can determine whether capital comes from private or public sources. We concur with Hannan and Carroll that the effects of policy have been largely untheorized but do not agree that it is because policy is of little theoretical importance.

Because policy is untheorized, its empirical importance has been overlooked by analysts who focus on relatively trivial policies. In one study of regulation, for instance, RangerMoore, Banaszak-Holl, and Hannan (1991) showed that foundings of Manhattan banks decline when the government expands the requirements for receiving a charter. Regulatory barriers to entry were surely important, but of far more importance in nineteenth-century banking were the government subsidies that spawned banks throughout the South and West (Callender, 1902). To theorize the effects of policy more adequately, we outline the effects of policy expected by business historians and organizational institutionalists and then sketch railroad history to develop specific hypotheses. We then enumerate hypotheses derived from research in population ecology and industrial organization economics.

\section{HOW POLICY SHAPES COMPETITION}

Business historians and organizational institutionalists have argued that public policy structures the competitive environment. Policy creates the basic structure of the corporation, the basic organization of finance, and the basic rules governing industrial competition (Lindberg and Campbell, 1991; Fligstein, 1996; Roy, 1997). Public policy in these last two realms influenced capital availability and competition for customers, respectively, and thereby influenced foundings of railroads. Effects of the two principal policies we discusspublic capitalization and public regulation of competitionhave also been found in ecological studies (for a review, see Baum 1998). We build on the convergent arguments of business historians, organizational institutionalists, and organizational ecologists, which depend on a common understanding of the strategies business has constructed to deal with each policy regime. The factors we discuss shape the wider in- 
dustry market, not only foundings. Each affects mergers, for instance: pro-cartel policies remove the incentive to merge in order to stabilize prices, whereas antitrust policies encourage mergers among competing firms.

\section{Public Capitalization}

Business historians have argued that early public capitalization of American industry had dramatic effects on the establishment of canals, banks, railroads, and factories. Hartz (1948) showed that in Pennsylvania, public capital created the corporations that provided the state's transport and financial infrastructure (see also Callender, 1902; Handlin and Handlin, 1947; Lipset, 1963). Goodrich (1960, 1968) argued that the "state in-state out" pattern of government financing in the United States left publicly capitalized firms in private hands, and according to Graham (1991). American states and localities have continued to establish desired enterprises by offering overt and covert capital contributions.

Recent institutional studies lead to similar conclusions: when all else is equal, public contributions of capital increase the rate at which entrepreneurs found new firms. Dunlavy's (1993) institutional analysis of early Prussian and American railroading demonstrated that the generous contributions of American states stimulated foundings (see also Dobbin, 1994). Roy (1997) concurred, arguing that the metamorphosis of the public-interest corporation into the private-interest corporation has obscured the important role of public initiative in American industrial development. The studies in Campbell, Hollingsworth, and Lindberg (1991) show that government capitalization, in various forms, has boosted foundings in a wide range of industries.

In line with these institutional analyses, ecologists have shown that public expenditures influence foundings of human service organizations. Baum and Oliver (1992) showed that social assistance expenditures affect day care center foundings, while Singh, Tucker, and Meinhard (1991) showed that funding for youth programs affects social service organization foundings. Conversely, when the government drains resources, organizations suffer. Wholey, Christianson, and Sanchez (1992) showed that when states require a security deposit from health maintenance organizations (HMOs), failures among small HMOs rise. We expect to find that public capital contributions boost foundings of railroads.

\section{Regulation of Competition: Antitrust and Pro-cartel Policies}

Business historians have also studied the effects of two forms of regulation; antitrust policies, which enliven competition, encouraging concentration and discouraging foundings, and pro-cartel policies, which quash competition, discouraging concentration and encouraging foundings. Chandler (1990) explained the divergence of American and German industry structure in part by the rise of antitrust law in the U. S. and the persistence of pro-cartel policies in Germany. In the U. S., enforcement of the Sherman Antitrust Act by the Supreme Court in 1897 elevated competition, increasing concentration and reducing foundings in a wide range of in- 
dustries. If, Chandler argued, "interfirm agreements on rates, allocation of traffic, and pooling of profits had been legally enforceable in the courts, as they were in other countries, a powerful incentive" for concentration would have been removed (1990: 57; see also McCraw, 1984). In Germany, Chandler argued, pro-cartel policies stabilized industries and forestalled concentration. During the heyday of the American cartel, similar effects were observable. Kolko showed that before 1887. American railroading had stabilized under a pro-cartel regime that shielded incumbents. In late nineteenth-century America, cartels emerged to check competition in industries as wide-ranging as metals, mining, lumber, paint, explosives, paper, and footwear (Schneiberg and Hollingsworth, 1989). Rare was the industry that operated without cartels. Long after the Supreme Court upheld antitrust laws, cartels continued to check competition and industrial concentration in America's international rivals: Germany (Chandler, 1990), Britain (Florence, 1953), France (Hayward, 1986), and Japan (Johnson, 1982).

Organizational institutionalists have examined antitrust and pro-cartel policies from the perspective of the firm and entrepreneur. Fligstein (1990) showed that antitrust policy had dramatic effects on firm and industry structure, enlivening competition and thereby discouraging market entry. Paradoxically, antitrust policy led firms to seek monopolies as the only remaining means to controlling price competition (see also Hollingsworth, 1991: 41). To maintain their monopolies, incumbents sought to destroy entrants, which discouraged foundings. We expect antitrust policies to discourage foundings by stimulating competition.

Cartels show much the opposite effect in institutional studies. As Lindberg, Campbell, and Hollingsworth (1991) suggested, a properly operating association will stabilize prices and apportion production, precluding price wars and other predatory practices. Associations create an environment that is hospitable to incumbents and therefore attractive to prospective entrants. Thus, cartels encourage foundings by dampening competition. Pro-cartel policies may be particularly salient in industries such as railroading, where high fixed costs and low marginal costs create a strong incentive for firms to engage in price wars (Tirole 1988).

Ecological studies support the idea that pro-competition policies reduce foundings and increase failures. Several have examined policies that change the competitive relationship between two groups of organizations. Strang and Uden-Holman (1998) showed that when public policy recognizes and protects health maintenance organizations, foundings of a competing type of medical provider, the independent medical practice association, decline. Amburgey, Dacin, and Kelly (1994) found that when the National Credit Union Administration allowed credit unions to mimic banks, competition between the two forms threatened credit union survival. Freeman and Lomi (1994) showed that a regulatory barrier between Italy's rural cooperative banks and national banks reduced competition for rural banks, raising foundings, while Barnett and Carroll (1993) found that early telecommunications regulation had the unintended consequence of stimulating competition among Bell and its smaller rivals, endan- 
gering the rivals. While these studies do not speak directly to the effects of pro-cartel and antitrust policies, they do suggest that policies regulating competition will influence the rate at which new firms are founded.

In summary, business historians, organizational institutionalists, and ecologists have suggested that public capitalization policies should stimulate foundings, policies that dampen competition should stimulate foundings, and policies that enliven competition should depress foundings. To define what these ideas mean for the pattern of railroad foundings we outline the history of railroading in Massachusetts under three successive policy regimes. We develop concrete hypotheses about the effects of public policy on foundings.

\section{Policy Regimes in Massachusetts Railroading}

Public capitalization policy regime: 1825-1871. American state and local governments actively promoted early industries with the conviction that public leadership in economic development was the incarnation of democratic self-rule (Tocqueville, 1945; Lipset, 1963). In the words of Shonfield (1965: 303), "At times the degree of tutelage which state governments arrogated to themselves in Jacksonian America appears so extreme that it suggests the direct inspiration of Colbert, rather than anything that belongs to the AngloSaxon tradition." States showed no hesitation in using public funds to help found private organizations that would benefit the community at large. When Massachusetts legislators saw the need for a bank, a canal, a railroad, or a factory, they were quick to proffer loans, stock subscriptions, land grants, and public bonds to willing entrepreneurs (Handlin and Handlin, 1947; Hartz, 1948). The legislature practiced what economic historians would later call "rivalistic state mercantilism" in the promotion of private canals, banks, turnpikes, factories, and railroads (Scheiber, 1981: 131). As early as 1828, Massachusetts legislators determined that they would finance a westward rail route to compete with the projects of seven other eastern states. The governor argued that public capitalization would promote the public interest and would fracture no constitutional principles (Massachusetts, General Court of, 1828: 25-26). Municipal governments were similarly activist and generous (Kennedy, 1961).

Massachusetts and its municipalities provided substantial capital to railroads. Aid came in the form of stock subscriptions, loans, bond guarantees, and grants. By 1870, Massachusetts municipalities had voted stock subscriptions totaling $\$ 2,351,000$ (Massachusetts, Board of Railroad Commissioners, 1871: ix; Fisher, 1947). Between 1837 and 1870, the state provided $\$ 11,290,000$ in loans to eight railroads (Cleveland and Powell, 1909: 218). In total, the state guaranteed more than $\$ 38,000,000$ in railroad bonds (Adams, 1893: 56). State and municipal legislatures regularly contributed tracts of land to railroads and sometimes made cash grants as well. It has been estimated that state and local governments provided 40 percent of the capital used to build railroads in the 1830s and 1840 s and as much as one-half of the total capital invested before the Civil War (Locklin, 1954: 107; Goodrich, 1968: 66; Dunlavy, 1991: 12). 
This period came to an abrupt end in 1870, when railroad finance scandals led Massachusetts to forswear state aid to new projects and limit municipal construction aid to 5 percent of costs (Cleveland and Powell, 1909: 237-240; Henry, 1945; Goodrich, 1960: 231-236). The problem of corruption was widespread: fourteen other states amended their constitutions to prohibit all public aid to private enterprise. In 1872, the United States Congress likewise swore off future aid in the wake of a railroad finance scandal that centered on Oakes Ames, a Republican congressman from Massachusetts (Thompson, 1983: 170; Bruchey, 1990: 201).

From 1825 to 1871 , public contributions and bond guarantees more than doubled the resources available for founding railroads. Prospective railroaders considered public backing before all else when deciding whether to build a line. As the president of one large railroad wrote in 1888, the decision to found a railroad had depended, "first upon the amount of [public] aid which [could] be obtained; second, the relative cost; . . . third, the amount of business" forecasted (from Cochran, 1965: 402). Public aid ensured that Massachusetts' rail system was built well ahead of demand (Adams, 1893).

Beyond expanding the pool of founding resources, public capitalization mitigated railroaders' worries about competition. Because governments were ready to contribute additional funds to railroads that could not meet their expenses, entrepreneurs often developed new routes without any attempt to forecast a rate of return or to identify direct competitors (Cochran, 1965: 128). We expect this period of public capitalization to have a strong, positive, effect on railroad foundings:

Hypothesis 1: The public capitalization policy regime (1825-1871) will have a positive effect on foundings.

Industrial organization economists have neglected the role of public capitalization, and ecologists have limited their analyses to the effects on nonprofits (Baum and Oliver 1992; Singh, Tucker, and Meinhard 1991). These camps tend to assume that markets achieve equilibrium or are constrained by carrying capacity, such that public capitalization would have only fleeting effects that would soon be corrected by the laws of supply and demand.

Public bond schemes to draw British capital. To draw capital from London where it was plentiful, states and localities issued guaranteed railroad bonds in British sterling (Heydinger, 1954; Chandler, 1965: 45). The practice was quite successful, and public bonds designed for sale in London soon became the most common form of government subsidy. As a consequence, we expect $U$. S. railroad foundings to be sensitive to the vicissitudes of the British economy.

As early as 1833, Massachusetts financed the Western Railroad by issuing four million dollars' worth of bonds in British sterling (Massachusetts, Committee on Railways and Canals, 1839: 54; 1845: 110). More than half of the $\$ 90$ million that had been invested in America's northern railroads and canals by 1836 had been raised through the sale of public bonds in England. By 1854, foreign investors held 58 percent of all bonds issued by American states (Willis and Bogen, 1936: 211-220). Even after states forswore public aid at the end of 
the 1860s, local governments and New York banking houses marketed their own bonds directly in London. Thus, between 1871 and 1875, after states had forsworn public aid, U. S. rail promoters offered bonds valued at $\$ 275$ million in London (Cleveland and Powell, 1909: 217; Willis and Bogen, 1936: 226; Goodrich, 1960: 128). By the early 1890s, European holdings of American rail bonds totaled nearly $\$ 2$ billion (Willis and Bogen, 1936: 224-230).

Transport historians have noted that in several periods the American rail industry appears to follow the fortunes of the British economy (Heydinger, 1954; Chandler, 1965: 45; Parris, 1965; Simmons, 1978: 40). For instance, when British capital markets were flush in the 1840s, both Britain and the U.S. saw dozens of railroads founded; when a recession hit Britain, foundings declined in both places. By contrast, the economic historian Harley (1982) has demonstrated that railroad construction bursts in the western states did not follow the vicissitudes of American financial markets. Thus, we offer a second hypothesis about the effects of public capitalization policies:

Hypothesis 2: As a consequence of state policies designed to draw British capital, growth of the British economy will better predict foundings than will growth of the U. S. economy

Pro-cartel policy regime: 1872-1896. Just when the well of public capital was drying up in the early 1870s, two government actions fostered cartels and thereby boosted foundings. Cartels were fostered in part by rate regulation, which stimulated price competition by outlawing monopolistic pricing, and in part by governmental calls for railroad cooperation. The cartels dampened competition by fixing prices, allocating or "pooling" traffic among railroads, and pooling profits. Every American railroad of any size joined a cartel in these years.

State-level rate regulation stimulated competition by undermining monopoly pricing and created demand for a mechanism for halting rate wars. The centerpiece, in Massachusetts, was the short-haul law of 1871 . At the time, railroads offered below-cost rates on routes where they faced competitors and exorbitant rates on routes where they held monopolies. This system favored cities, which were typically served by multiple carriers. From Boston, it was cheaper to send freight to the city of Worcester than it was to send it to a rural town halfway to Worcester (Adams, 1893: 124). As the Massachusetts Board of Railroad Commissioners (1881: 31) later argued, it was unjust that a railroad should charge "twenty dollars for not hauling" a load of wheat one hundred additional miles. The short-haul law of 1871 made it illegal to charge more for short-distance transport than for long-distance transport along the same route. The short-haul law meant that competitive routes would set the benchmarks for railroads' entire rate structures. If railroads did not find a way to quash competition so that they made money on routes where they faced rivals, they would lose money on all routes. The law encouraged railroads to join cartels to fix prices on competitive routes (Wilcox, 1960: 5-22; Sanders, 1981). 


\section{Railroad Foundings}

Soon after passage of the short-haul law, Massachusetts began to promote railroad cartels as a way to stabilize prices and protect public capital. When American legislators looked to British railroads in the 1860 s and '70s to see what the future held, they saw extensive cartelization. In 1866. Congress stimulated railroad cooperation with a law facilitating the sharing of rolling stock and track (McCraw, 1984: 49; Kennedy, 1991: 145). From the early 1870s, Massachusetts' Board of Railroad Commissioners encouraged collective ratesetting through cartels. By 1875, the board publicly extolled cooperative pricing, arguing that competitive pricing had led to "fierce contests and violent fluctuations of very short duration" that destroyed firms, rather than to properly regulated rates (Massachusetts, Board of Railroad Commissioners, 1875: 41). They soon argued that "uncontrolled competition is but one phase in railroad development and must result in some form of regulated combination" and argued for overt, formal price-setting arrangements (1878: 80). In Massachusetts, both the legislature and the Board of Railroad Commissioners favored cartels during the 1870 s and 1880s.

Most other states likewise promoted cartels and regulated rates, and, in short order, railroads across America were participating in cartels. By 1874, Amasa Stone, who directed railroads in Massachusetts, Connecticut, and the Midwest, argued "there will be little value in railroad property without general cooperation of competing lines" (from Cochran, 1965: 469). Massachusetts freight agents had met informally since the 1850 s to try to quash rate competition, but in 1874 the "Saratoga Combination" created a new model for ratefixing, with a bureau that would monitor charges and sanction railroads that undercut collective rates. The new Western Railroad Bureau, which governed traffic between the East and Chicago, was designed "not only to establish common rates, but to make those rates binding upon each party to the combination through a central executive organization" (Massachusetts, Board of Railroad Commissioners, 1878: 65). In Massachusetts, a Boston-Portland pool was established in 1874, and soon all major competitive railroads had joined cartels modeled on the Saratoga group (McCraw, 1984: 49).

The pro-cartel policy environment came to an end not in 1887 when Congress passed the anti-cartel Interstate Commerce Act, not in 1890 when Congress passed the Sherman Antitrust Act outlawing cartels as a "restraint of trade," but in 1897, when the Supreme Court upheld the Commerce and Sherman acts as they applied to railroads. Between 1887 and 1896. American railroads continued to participate in cartels in the belief that the courts would ultimately condone cooperation (MacAvoy, 1965).

The period of pro-cartel policies dampened railroad competition. As cartel proponent Albert Fink (1979: 22-23) argued before Congress in 1880, the rate association "preserves the individuality of each road. ... It makes the separate, individual existence of these roads possible, and puts a check upon the consolidation of roads." Fink convinced the industry that the associations could guarantee "the separate existence of a great number of competing roads" by stabilizing 
the income of independents. Harley's (1982) study of railroad construction after the Civil War demonstrates the effects of cartels on railroad expansion. The western cartels disintegrated several times. When they were operating smoothly, railroad construction proceeded slowly and followed demand. When cartels broke down, railroads built new lines ahead of demand in the hope of capturing new markets. Cartels led incumbents to assume the industry would be stable and predictable, and prospective entrepreneurs found the cooperative relations among railroads encouraging. We expect that the pro-cartel regime will raise foundings by dampening competition among incumbents and by suggesting that new firms could prosper:

Hypothesis 3: The pro-cartel policy regime (1872-1896) will have a positive effect on foundings.

Antitrust policy regime: 1897-1922. The keystone of federal railroad regulation, the Interstate Commerce Act of 1887, forbade traffic pooling and price fixing. Two years later, the Sherman Antitrust Act forbade "restraints of trade" in all industries, including pricing arrangements that precluded competition. Railroads responded not by quitting cartels but by restructuring them and asking the courts to strike down the Commerce and Sherman acts (Hilton, 1966; MacAvoy, 1965; Ripley, 1915: 588). In 1897, the Supreme Court surprised the industry by upholding the core substantive clauses of both acts, which proscribed pooling and rate fixing (U. S. v Trans-Missouri Freight Association 166 U. S. 290 [1897]) (Binder, 1988).

The Trans-Missouri decision produced aggressive competition in railroading. Ruinous rate competition, and the fear of such competition, led to an unprecedented merger wave between 1897 and 1903 (Bittlingmayer, 1985). Annual railroad mergers in the United States, which numbered 35 or so between 1890 and 1896, rose to nearly 80 in 1897 and nearly 130 by 1900 (Ripley, 1915: 458). One-eighth of $U$. S. rail mileage $(25,000$ miles $)$ was ceded to other lines in the 18month period that began in July 1899 (Chandler, 1977: 172). In Massachusetts, where the legislature had been reluctant to grant new charters to merged railroads, railroads often leased competing firms in their entirety instead of merging (Massachusetts, Board of Railroad Commissioners, 1898; Kirkland, 1948, 1: 381). The paradox of antitrust was that while it prohibited cartels designed to halt competition, it did not stop mergers and leasing arrangements designed for the same purpose (McCraw, 1984: 51; Fligstein, 1990: 35; Hollingsworth, 1991: 41).

Antitrust enforcement stimulated price competition among railroads. Such industry leaders as Charles Francis Adams, Massachusetts' first railroad commissioner, Albert Fink, leader of the rate association movement, and Henry Carter Adams, the prominent railroad economist, had already predicted that without a system of rate cooperation the industry would destroy small competitors and move toward consolidation. A corollary was that under fully competitive conditions, new firms could not hope to survive (Skowronek, 1982: 133; McCraw, 1984: 51). We predict that from 1897, when antitrust spawned competition, railroad foundings will decline: 


\section{Railroad Foundings}

Hypothesis 4: The antitrust policy regime (1897-1922) will reduce railroad foundings.

In Massachusetts, antitrust stimulated a wave of leasing agreements rather than a wave of acquisitions, because the legislature was reluctant to grant charters to merged railroads. We do not expect this difference to diminish the negative impact of antitrust on railroad foundings.

Periods in economic history. Economic historians have argued that during the century we examine, the American economy went through five economic periods, marked by wars and depressions (Fishlow, 1966; Carter and Sutch, 1992; Atack and Passell, 1994). Because these periods overlap with ours, we tested their effects to discover whether our policy regime variables were actually capturing wider economic changes. The first period runs from 1825 to 1860, the dawn of the Civil War; the second covers the war and Reconstruction: 1861-72; the third runs from 1873 to the depression that began in 1893; the fourth, from 1894 until the start of the Great War. The final period begins in 1914 and runs to 1922, at which point our data end.

Hypothesis 5: The five major periods in economic history will predict foundings better than the three policy regime periods will.

\section{Population Ecology and Industrial Organization Theories}

Next we turn to the factors shown to be important in the studies of organizational ecologists and industrial organization economists.

Population effects. Studies of organizational populations have shown that across a wide range of industries, the number of firms founded in any year is a function of competition for founding and operating resources. One element is the level of competition from existing firms: large numbers of competitors discourage prospective founders. Another element is the availability of resources. Resource availability is affected by the legitimacy of the organizational form, the number of recent foundings (which take up resources), the number of recent failures (which free up resources), the market niches left unmined, the number of network ties available in network-based industries, and the condition of capital markets.

Number of incumbents. As an industry approaches the environment's carrying capacity-the maximum number of firms that can be supported-foundings decline because demand is being filled by existing firms. Prospective market entrants are discouraged by the presence of adequate numbers of enterprises to fill demand and the prospect of facing competition from those enterprises. Thus, ecologists expect the number of firms (i.e., density) in an industry to decrease foundings (Hannan and Freeman, 1987; Barnett and Amburgey, 1990).

Legitimacy of the organizational form. In new industries, each additional firm helps to demonstrate the viability and improve the legitimacy of the industry and thereby attracts resources for founding more firms. Thus, when the population of firms is far below the environment's carrying capacity, each additional firm has a positive effect on future foundings. This empirical finding may capture diverse elements of 
legitimacy, including the political power of the form, its reputation, vicarious learning, and the growth of the institutional infrastructure (Delacroix and Rao, 1994: 31). Some suggest that the empirical finding may be spurious (Zucker, 1989; Peterson and Koput, 1991). Whether it picks up legitimacy in the narrow sense or a range of related factors, density has shown quite robust effects in ecological analyses. Density has a curvilinear effect on foundings and is modeled with a quadratic $\left(x-x^{2}\right)$ in which the first term $(x)$ represents legitimacy, and the second term $\left(-x^{2}\right)$ represents competition (see Hannan and Carroll, 1992; Delacroix and Rao, 1994, for reviews of findings). The effect of incumbents on competition is also expected by industrial organization economists, but the effect on legitimacy is not (Hannan and Carroll, 1992: 21). The first density term has shown the strongest effects in heavily regulated industries, where legitimacy helps to lower the political barriers to entry (Delacroix and Rao, 1994). Railroading is such an industry.

Hypothesis 6: Density will have an inverted U-shaped effect on foundings.

Capital availability. Foundings in one year stimulate foundings in the next by signaling to prospective entrepreneurs that the time is right: capital markets, customer demand, interest rates, tax code provisions, and other conditions favor market entry (Delacroix and Carroll, 1983; Carroll and Huo, 1986: 849; Delacroix and Solt, 1988; Hannan and Freeman, 1989: 232; Tucker, Singh, and Meinhard, 1990). Very high numbers of foundings in one year may exhaust available capital, however, making it difficult to assemble the resources necessary to found a firm in the next year (Hannan and Freeman, 1989: 232). Thus, like density, prior foundings typically show an inverted U-shaped effect on current foundings.

Hypothesis 7: Prior-year foundings will have an inverted-U shaped effect on foundings.

Recent failures also foster new foundings, because each "creates a fund of floating resources" that are available for new ventures (Delacroix and Carroll, 1983: 287). This is particularly true where asset specificity is high, as in railroading where abandoned routes cannot be converted to new uses. Typically, a failed railroad's receivers try to sell the route and stations at a price substantially below cost, which creates an attractive business opportunity. While each failure creates a business opportunity, previous studies have shown that massive numbers of failures signal a pernicious environment and may scare off prospective entrepreneurs and investors (Delacroix and Carroll, 1983: 287). Recent failures have been found to have an inverted U-shaped effect on foundings:

Hypothesis 8: Prior-year failures will have an inverted U-shaped effect on foundings.

We expect policy to condition the effect of failures in railroading. Because the legislature encouraged entrepreneurs to buy failed railroads (Handlin and Handlin, 1947), we expect to find a linear rather than curvilinear relationship between prior failures and current foundings. The legislature frequently succeeded in attracting new operators. After the Williamstown and Hancock failed in 1853, new operators were found to buy the route in the next year. After the Billerica and Bedford failed in 1878, new operators were found 


\section{Railroad Foundings}

in the next year (Massachusetts, General Court of, 1853 , $1854,1878,1880$ ). To the extent that the legislature was effective, each additional failure should increase foundings:

Hypothesis 8a: As a consequence of state policy on abandonments, prior-year failures will have a linear effect on foundings.

Vitality of capital markets. Population ecologists and industrial organization theorists alike expect the availability of capital to have a positive effect on foundings (Tirole, 1988; Hannan and Freeman, 1989). For ecologists, foundings depend both on the competition for resources and on the resources available-capital market vitality captures the latter. Following ecologists, we measure capital market vitality by economic growth in the previous year.

Hypothesis 9: Growth of the U.S. economy in the prior year will affect foundings.

Mutualism in network-based industries. Mutualistic industries include those like telephony and railroading in which a new firm's success depends on the total number of available network connections (Barnett and Carroll, 1987; Barnett and Amburgey, 1990; Hannan and Carroll, 1992). In railroading, a firm's prospects depend on the number of destinations available in the whole network. A firm servicing Boston-Worcester, for example, can expect more business if railroads connect Worcester to Albany, Burlington, and New York City than if they do not. In such industries, mass, or total industry size, may have a positive effect on foundings net of the effect of density (Barnett and Amburgey, 1990: 98; Hannan and Carroll, 1992):

Hypothesis 10: Network size will have a positive effect on foundings.

Resource partitioning. Carroll (1985) argued that industry concentration may encourage foundings by partitioning markets into mass and specialist segments. Over time, scale economies lead generalist firms to move toward the center of the market, creating space in specialist niches for new firms (Carroll, 1985; Hannan and Carroll, 1992: 160; Carroll and Hannan, 1995: 216). This type of resource partitioning is typical of railroading, where generalist firms moved to serve the mass market - the main east-west and north-south intercity routes-and specialist firms arose to provide spur line service to remote locales. The concentration of the industry in a few large firms should create room at the periphery for specialized firms and boost foundings. Concentration is sometimes used as a control for density, because the low density, low concentration common in young industries has very different effects from the low density, high concentration found in older industries (Hannan and Carroll, 1992: 48).

Hypothesis 11: Industry concentration will have a positive effect on railroad foundings and will condition the effect of density.

Industry effects. In economics, game-theoretic industrial organization (IO) scholars have also considered the effects of competitive processes on market entry. 10 theorists have specified the conditions that create barriers to market entry by making it difficult for new endeavors to succeed (Bain, 1956; Stigler, 1968; see also Coase, 1988). Organizational sociologists have rarely tested 10 hypotheses, two of which 
run directly counter to the mutualism and resource partitioning hypotheses.

Capital accumulation and the costs of production. 10 theorists have argued that in industries characterized by high fixed costs, such as railroading, capital accumulation reduces production costs for incumbents, thereby making it difficult for new entrants to compete. This creates a barrier to entry. Thus, rather than having the positive effect on foundings that population ecologists posit, mass measured as cumulative capitalization should have a negative effect (Stackelberg, 1952; Tirole, 1988: 306):

Hypothesis 12: Capital accumulation will have a negative effect on foundings.

Concentration and scale economies. In industries characterized by economies of scale, such as railroading, large firms have a competitive advantage. Prospective market entrants will perceive the presence of large firms to undermine their likelihood of success and will not enter the market. Thus, industry concentration serves as a barrier to entry (Bain, 1956; Shepherd, 1979: 183). Rather than having a positive effect through resource partitioning, concentration will have a negative effect:

Hypothesis 13: Industry concentration will have a negative effect on foundings.

\section{METHOD}

\section{The Data}

We analyzed time series data on Massachusetts railroad foundings between 1825 and 1922. We studied one state because states determined the policy environment for much of the period and because comprehensive national data on foundings, capital, and revenues do not exist for years before 1887. For foundings, no national data exist before Henry Poor's manual of 1860, and both Poor's manuals and the annual Interstate Commerce Commission series, begun in 1887, cover only the larger railroads (see Poor, 1860; Fishlow, 1966). We chose Massachusetts because it was the first American state to grant a railroad charter and because the commonwealth published quite complete railroad data.

Our data set offers certain advantages over other industrylevel data sets (see Tucker, Singh, and Meinhard, 1990: 156157). First, whereas many data sets lack information on the earliest foundings, ours contains full information because railroads held public charters. Second, it is often difficult to establish the founding date of a firm, but a railroad's charter date provides a good approximation. The legislature demanded that railroad promoters show earnest intent by producing engineering plans and drafts of chartering legislation and did not willfully deny charters for ideological or political reasons, as did European legislatures (Adams, 1893; Cleveland-Stevens, 1915; Doukas, 1945). Finally, annual reports published by the commonwealth contain data on a number of salient covariates, such as income, track mileage, and capitalization. 


\section{Railroad Foundings}

\section{Variables}

Foundings. We have complete data on foundings for 1825 , when the Granite Railway won the first charter granted in the United States, through 1922. We examined each of the state's annual railroad reports for evidence of foundings (Massachusetts, Committee on Railways and Canals, 18381856; Massachusetts, Secretary of the Commonwealth, 1857-1869; Massachusetts, Board of Railroad Commissioners, 1869-1922). Next, we cross-checked founding dates in the commonwealth's annual Acts and Resolves of the General Court (1825-1922), which contains copies of rail charters. Finally, we cross-checked once again for the early period in Henry Poor's History of the Railroads and Canals of the United States of America (1860). There were 318 railroads chartered between 1825 and 1922, excluding charters granted to local street car lines and those granted to incumbent firms when they acquired other firms or entered receivership. We truncated the analysis in 1922 because Massachusetts ceased publishing annual reports in that year. Foundings were rare thereafter.

Figure 1, which graphs Massachusetts railroad foundings and density, shows the effects of policy regimes on foundings. Under the public capitalization policy regime (1825-1871), there were several periods with many foundings, including the 1840s, when British capital markets were flush. A decline in foundings in the 1850 s followed a recession in Britain. Under the pro-cartel policy regime (1872-1896), foundings remained moderately high, and under the antitrust regime (1897-1922), foundings declined to near zero.

The dependent variable is the number of railroad charters granted by the legislature each year. We omitted the year of the first founding, 1825, because the value is constrained to

Figure 1. Massachusets rabroat foundings and density.

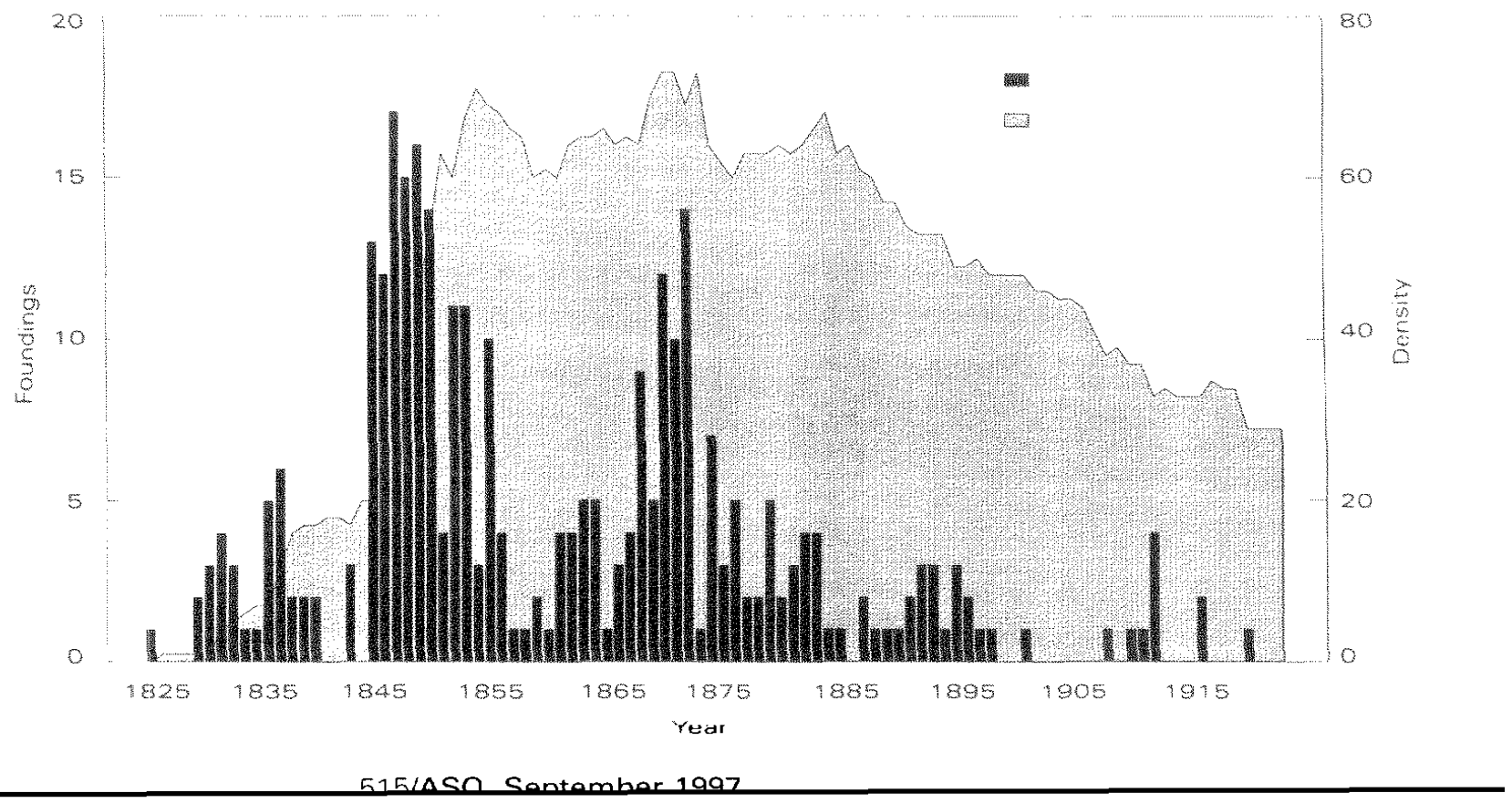


be greater than zero (Ranger-Moore, Banaszak-Holl, and Hannan, 1991). We analyzed annual counts rather than actual charter dates because the annual legislative session often lasted only a few months, hence, charter dates are bunched together. Lagged foundings and lagged foundings squared serve as independent variables.

Density. We coded density in two different ways. Following prevailing practice, we coded density as the number of firms surviving at year's start, calculated as cumulative foundings minus cumulative failures. Independent density is the number of autonomous firms at the beginning of the year, computed as simple density minus the number of wholly leased firms. Because other modes of transport did not challenge the supremacy of railroads until the rise of motor carriages in the 1920s, we did not consider competition from other transport industries (Locklin, 1954: 269; Bruchey, 1990: 420; Kennedy, 1991: 169). In Massachusetts, the coastal merchant marine offered some competition to railroads, but neither canals nor turnpikes were well developed before railroads were built (Kirkland, 1948, 1: 17; Atack and Passell, 1994: 156). Data on ocean traffic were never collected by the commonwealth.

To capture the rapidly changing carrying capacity of Massachusetts during the industrial revolution, we used several measures of the size of the market: state population, gross state product, and gross national product.

Failures. A railway fails when it declares bankruptcy, enters receivership, or is acquired by another firm. While acquisitions are not technically failures, we treat them as such to replicate previous studies. Some railroads expired without experiencing any of these events; those we code as failed in the year the railroad permanently halted construction, ceased to operate, or last recorded legal action. Figure 2 graphs failures and density over the study period. Figures 1 and 2 together show a close connection between foundings and failures, particularly in the periods 1844-1855 and 1867-1874. This captures both the liability of newness, in which foundings lead quickly to failures, and the legislature's policy of encouraging new operators to take over failed lines, in which failures lead quickly to foundings. Figure 2 shows that after the Trans-Missouri decision stimulated price competition in 1897, 30 railroads failed. This does not reflect the full effect of Trans-Missouri, because the legislature's reluctance to grant charters to merged railroads caused companies to lease rather than acquire their competitors. As a consequence of widespread leasing, after the turn of the century there were never more than 12 railroads operating independently in the state, and the vast majority of track was controlled by only 4 companies. Such concentration in the context of a pro-competition regulatory regime discouraged foundings.

Vitality of the U.S. and British capital markets. We operationalized the vitality of each capital market with the number of months the economy held steady or grew in the previous year. We used this measure to replicate population ecology 


\section{Railroad Foundings}

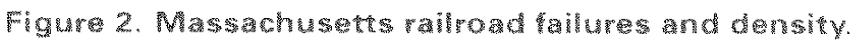

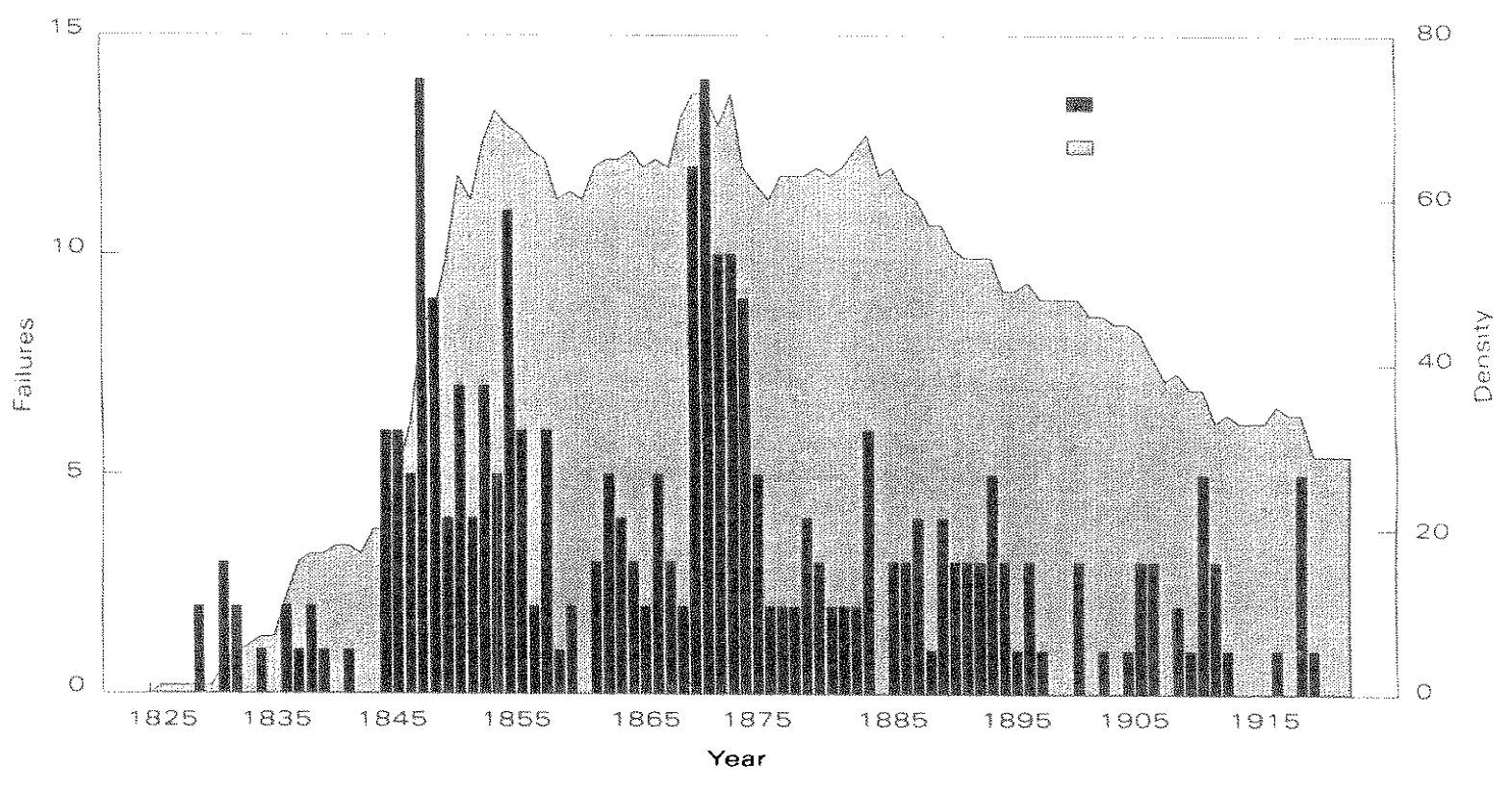

studies. Each variable was constrained to range from 0 to 12. We set years in which the U. S. was at war to zero, because wars interrupted capital flows (Thorp, 1926; see Hannan and Freeman, 1989).

Network size/capital accumulation. To code network size and capital accumulation we used three alternative indicators from the commonwealth's annual reports. Mileage mass is the total, operating, track mileage in the commonwealth at the beginning of the year. Revenue mass is gross industry revenues. Capital mass, the measure most commonly used in previous ecological studies, is the cumulative capitalization of the industry. We collected data on each measure from the state's annual railroad reports, supplemented by other sources. For mileage, we corrected some of the state's reports with data from Poor's (1860) manual. We logged each measure to replicate previous studies (Barnett and Amburgey, 1990; Hannan and Carroll, 1992). Ecologists have found that network size has a positive effect on foundings in network-based industries. Industrial organization theorists have suggested that accumulated capital, capital mass, has a negative effect on market entry in industries with high fixed costs.

Concentration. We used the three preferred measures for concentration. Four-firm and eight-firm concentration reflect the proportion of total industry revenues accruing to the largest four and eight firms, respectively. The Herfindahl concentration index is the sum of the squares of the market shares of operating firms and is constrained to range from 0 to 1 (Tirole, 1988: 221). For instance, when a single firm supplies the market the Herfindahl index is $1^{2}=1.0$, and when two firms share the market equally it is $.5^{2}+.5^{2}=.5$. The market share of a railroad is its annual sales divided by total industry sales. Figures come from railroads' annual reports to the commonwealth. 
Public policy regimes. We represented the public capitalization (1825-1871) and pro-cartel regimes (1872-1896) with binary variables, omitting the antitrust regime (1897-1922). The public capitalization regime extends from the industry's beginning to 1871, when Massachusetts legislation curtailed public capitalization. The pro-cartel regime extends from the year after rate regulation legislation, 1872, to 1896. The antitrust regime begins with the Supreme Court enforcement of the Commerce and Sherman acts in 1897. The public capitalization period should show a strong positive effect on foundings. The pro-cartel period should also show a positive effect. We represented the five periods identified by economic historians with binary variables, omitting the first period.

Time trend. To test whether the decline in foundings over time is a secular trend, we used a time trend variable that ranges from year 1 to year 97 . We expect two stepwise changes in the baseline level of foundings following policy shifts. If, instead, the binary period variables are picking up a continuous decline, the time trend should wash out their effects.

Table 1 lists the independent variables used in the analysis and specifications omitted from results reported here.

Table 1

\section{Independent Variables}

\begin{tabular}{|c|c|}
\hline Variable & Definition \\
\hline 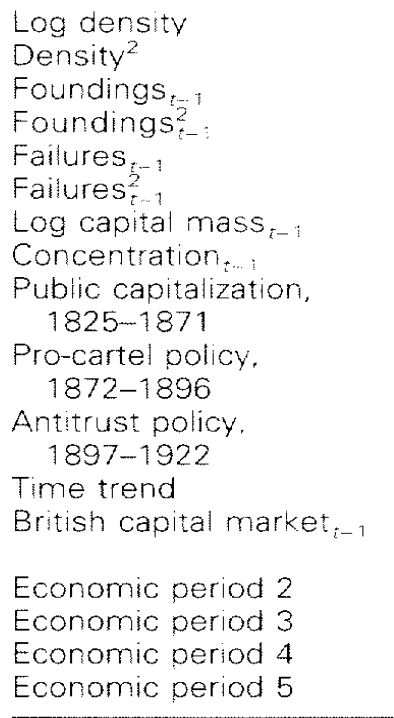 & $\begin{array}{l}\text { Natural logarithm of the number of railroads in existence at the beginning of the year } \\
\text { Square of simple density } \\
\text { Number of railroads chartered in previous year } \\
\text { Square of foundings } \\
\text { Number of railroads that faled in previous year } \\
\text { Square of failures } \\
\text { Log of total railroad capitalization in Massachusetts, in constant dollars } \\
\text { Herfindah concentration index; sum of squares of market shares of operating firms } \\
\text { Binary variable for public capitalization regime } \\
\text { Binary variable for pro-cartel regime } \\
\text { Omitted } \\
\text { 1-97 } \\
\text { Months British economy held steady or grew in } t-1 \text {, with years of U.S. war activity } \\
\text { set to zero } \\
\text { Binary variable for } 1861-72 \\
\text { Binary variable for } 1873-93 \\
\text { Binary variable for } 1894-1913 \\
\text { Binary variable for } 1914-1922\end{array}$ \\
\hline \multicolumn{2}{|c|}{ Specifications Omitted from Reported Results } \\
\hline 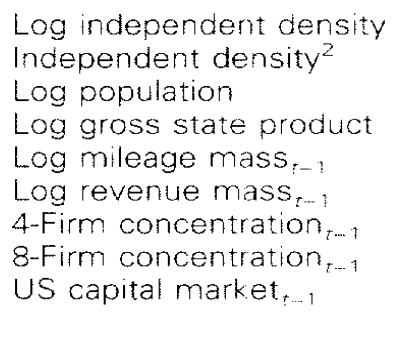 & $\begin{array}{l}\text { Log of number of non-leased railroads operating at beginning of the year } \\
\text { Square of independent density } \\
\text { Population of Commonwealth of Massachusetts } \\
\text { Gross product of Massachusetts } \\
\text { Log of total working rail mileage in Massachusetts } \\
\text { Log of total railroad revenues in Massachusetts, in constant dollars } \\
\text { Combined market share of four largest firms } \\
\text { Combined market share of eight largest firms } \\
\text { Months U.S. economy held steady or grew in } t-1 \text {, with years of U.S. war activity set } \\
\text { to zero }\end{array}$ \\
\hline
\end{tabular}




\section{Railroad Foundings}

\section{Analysis}

We used negative binomial regression to model railway foundings. Although analysts commonly use Poisson regression to model annual event counts, Poisson regression depends on the assumption that the conditional variance and mean of the number of events are equal,

$\operatorname{Var}\left(Y_{t}\right)=E\left(Y_{t}\right)$.

When the conditional variance exceeds the mean, however, overdispersion can lead to underestimated standard errors and, hence, to erroneous rejection of the null hypothesis. The quadratic parameterization of negative binomial regression we used corrects this problem with the specification, $\operatorname{Var}\left(Y_{t}\right)=E\left(Y_{t}\right)+\alpha E^{2}\left(Y_{t}\right)$

(Cameron and Trivedi, 1986; McCullagh and Nelder, 1989; Ranger-Moore, Banaszak-Holl, and Hannan, 1991; Barron, 1992). A $t$ test of the hypothesis that the overdispersion parameter, $\alpha$, differs significantly from zero verified overdispersion in every equation reported in table 2, below, confirming the need for negative binomial analysis (Barron, 1992: 211). A common cause of overdispersion is contagion across events within spells, which may occur when foundings at the beginning of the year stimulate foundings later in the year. We derived the estimates reported below by maximum likelihood estimation using the software package LIMDEP (Greene, 1990).

In count data, contagion across spells can produce autocorrelation. Barron (1992) recommended using a lagged count in cases such as ours (see hypothesis 7), where theory implies that the number of prior events affects the count in the current period. We tested models for autocorrelation using a lagged count.

To test hypotheses from competing paradigms, we entered variables in blocks. When we examined alternative specifications of a variable, we report results from the specification that showed the strongest effects. When the results for alternative specifications were substantively identical, we report results for the specification most frequently used in previous studies.

\section{FINDINGS}

Results of the quantitative analyses shown in table 2 support our predictions about the effects of policy on competition and railroad foundings. Public policies show robust effects on railroad foundings, and they condition competitive factors in important ways. First, density has the expected effects, boosting foundings by expanding resource availability at first and then depressing foundings by expanding competition, but only after the policy regimes have been introduced. Second, the public capitalization policy regime, which increased the pool of resources available for establishing railroads, has a large effect on foundings. Third, the pro-cartel policy regime, which dampened competition among incumbents, has a positive effect on foundings. Fourth, the policy of creating public bonds for sale in London, designed to attract British capital, caused Massachusetts railroad foundings to follow the vicissitudes of the British economy. Fifth, the legislature's policy of encouraging entrepreneurs to purchase and 
reopen failed railroads caused previous-year failures to have a positive and linear, rather than curvilinear, effect on current foundings. Finally, the multivariate results do not support industrial organization hypotheses. While capital accumulation and concentration initially show the effects expected by 10 theorists, their effects disappear in the presence of other variables.

The first equation reports a model containing the three principal variables previously used to measure resource availability and competition: density, prior-year foundings, and prioryear failures. In the absence of controls for policy regimes, only lagged births shows the expected effect. In results not reported here, we examined the effects of density, foundings, and failures separately. Only lagged foundings showed the expected effects. We also ran all models with an alterna-

Table 2

Estimates of Negative Binomial Regression Models of Massachusetts Railroad Foundings, 1826-1922 $(N=317)^{*}$

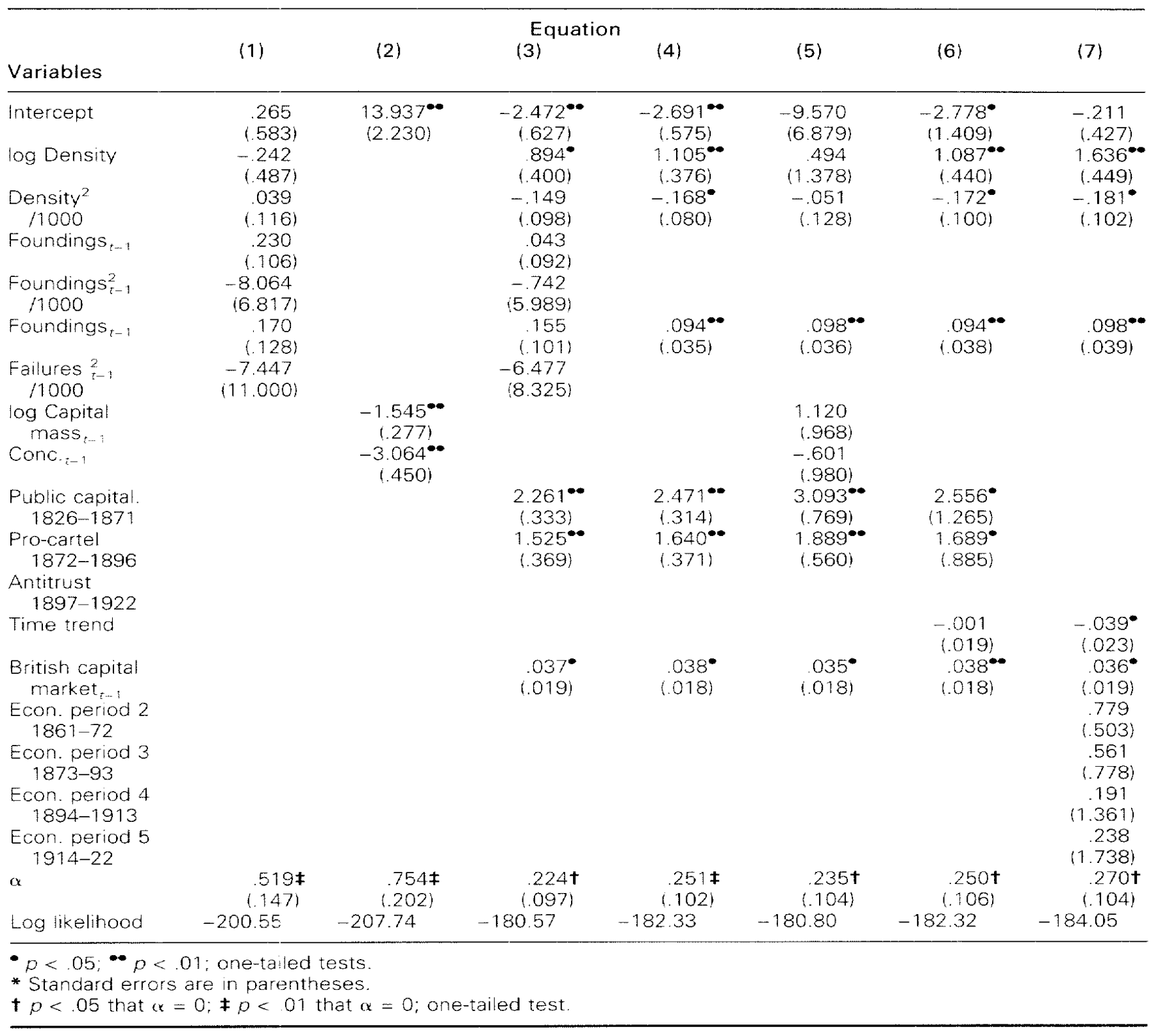




\section{Railroad Foundings}

tive measure of density, the density of independent railroads. This specification did not perform as well as density.

To explore whether population dynamics work as expected within policy regimes, we examined the effects of density within each period. In the first period (1825-1871), the coefficients showed the expected signs, and the coefficient for the first term was statistically significant. This suggests that population dynamics operate as expected under stable policy conditions.

The second equation reports a model containing two variables that both ecologists and industrial organization theorists tie to foundings. The predictions of the two groups of theorists run in different directions. Ecologists expect that network size, measured as total capitalization, will stimulate foundings. By contrast, 10 theorists argue that incumbent capital accumulation acts as a barrier to entry. The negative and significant results for capital mass are consistent with the 10 hypothesis. In results not reported here, we introduced two other measures of network size, total mileage and total revenues. Results for neither supported the mutualism hypothesis.

Ecologists expect that concentration in industries subject to resource partitioning will stimulate foundings. By contrast, 10 theorists argue that industry concentration acts as a barrier to entry. The negative and significant results for the Herfindahl concentration index are consistent with the 10 thesis. In results not reported here, we introduced two other measures of concentration, 4-firm and 8-firm concentration ratios. Neither supported the resource partitioning hypothesis. In the absence of controls, capitalization and concentration appear to serve as barriers to entry.

In equation ( 3 ), we added the public capitalization and procartel regime variables and British capital market to the three quadratics included in equation (1). The results are dramatic. First, density dependent legitimation shows a significant effect, whereas in the absence of the policy variables neither density term showed the expected effect. Policy regimes clearly condition competition.

Second, the policy regimes show significant effects. Public capitalization has a strong positive effect on foundings. The pro-cartel regime has a moderate positive effect on foundings. British capital market, which taps the effects of Massachusetts bonds designed to attract British capital, shows a strong positive effect. In multivariate models not reported here, we found that the U. S. capital market did not affect railroad foundings. This confirms our hypothesis that Massachusetts' policy of designing bonds for sale in London made the British capital market more salient than the U. S. capital market.

Large numbers of competitors depress foundings in this model and in subsequent models. Ecologists argue that density represents competition from incumbents and the carrying capacity of the environment. To sort out these two factors, we introduced a measure of industry capacity, mileage mass, to equation 4 (in results not reported here). It did not show significant effects. In figure 3 , which graphs track mile- 
age, mileage continues to increase until the end of the period, despite the fact that density and foundings decline.

In equation (4) we present a reduced form of the model presented in equation (3). To arrive at this reduced model, we replicated equation (3), eliminating the foundings and failures parabolas in turn. In these analyses, only the first term of the failures parabola showed a significant effect: hence, we retain only that variable in equation (4). In that equation, both terms of the density parabola show significant effects, as predicted. The effect of lagged failures confirms our hypothesis that the state's policy of encouraging entrepreneurs to buy bankrupt lines was important. That the effect is linear, rather than curvilinear, suggests that even at high failure rates, each additional failure increases foundings. In appears that policy mediates the effect of previous-year failures.

Prior foundings did not show the usual curvilinear effect, probably because public capitalization was a much better signal of hospitable founding conditions than were recent foundings. The equations in table 2 support such an interpretation, especially because equation (4) is more parsimonious than equation (3) while fitting the data equally well (compare the log likelihood statistics).

Density performs well in equation (4), and to explore whether it is capturing carrying capacity or competition, we introduced three more direct measures of carrying capacity (in models not reported here). Logged population, logged gross state product, and logged gross national product showed no net effects on foundings. It appears that density represents competition rather than carrying capacity in these models.

In equation (5) we introduce capital accumulation and concentration to the model reported in equation (4), our best-

Figure 3. Massachusetts railroad track mileage.

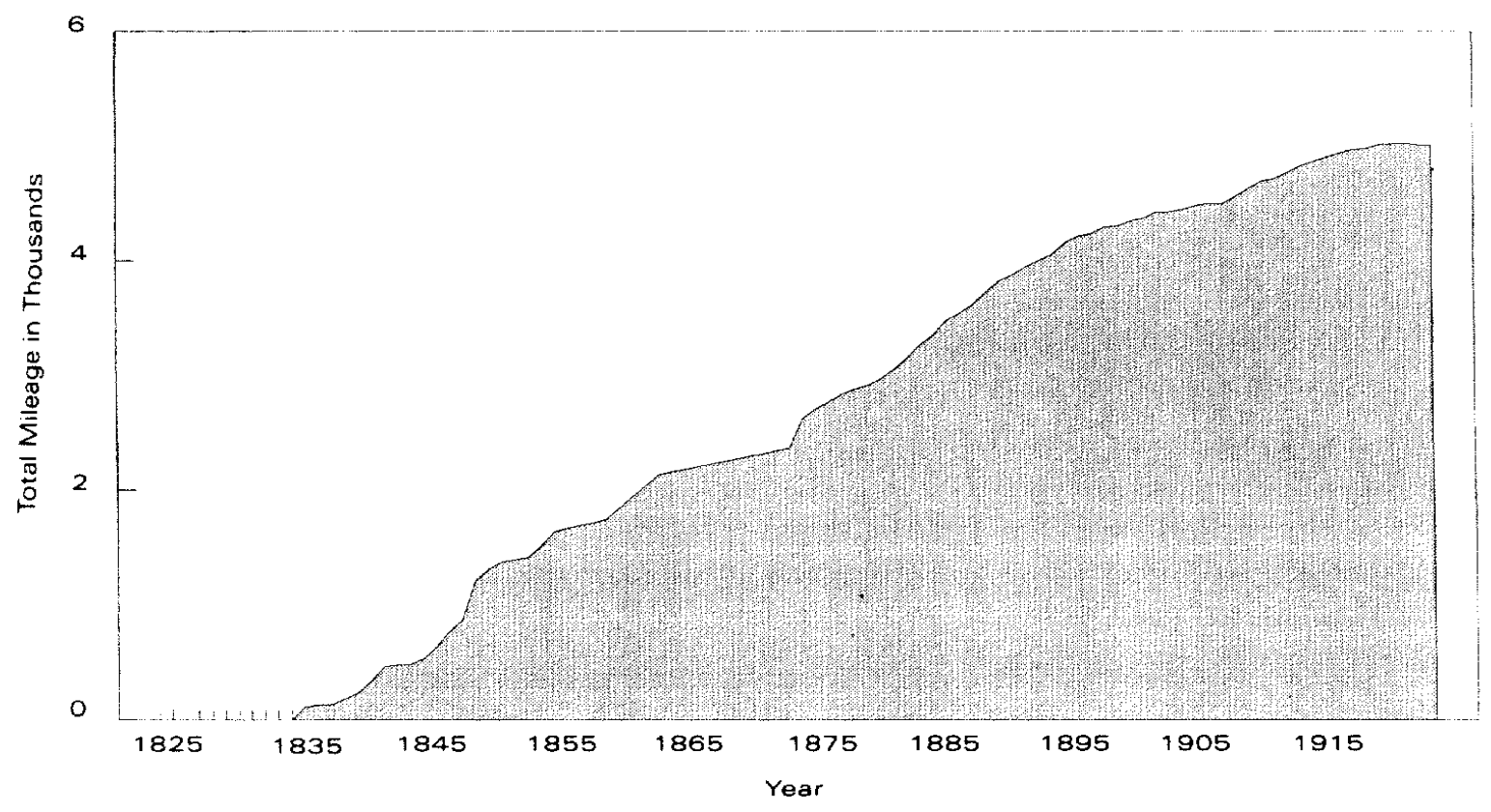

522/ASQ, September 1997 


\section{Railroad Foundings}

fitting model. In the presence of controls, the effects of capital accumulation and concentration disappear. In results not reported here, capital accumulation and concentration continued to show negative effects when we controlled for density, previous foundings, and failures, although the latter three variables failed to attain significance. Capital accumulation and concentration did not continue to show effects when entered with only the policy regime variables. It would appear that the effects of capital accumulation and concentration in equation (2) were spurious.

In equation (6) we introduce a time trend variable to the model reported in equation (4), the best-fitting model, to examine whether the two policy regime variables are simply picking up a secular decline in foundings. If this is the case, the time trend should show a significant, negative effect, should wash out the effects of the binary policy variables, and should improve the fit of the model. This is not what happens. The time trend does not show a significant effect, does not wash out the effects of the policy variables, and does not improve the fit of the model. Because the time trend is collinear with the two policy regime variables, we expect it to increase the standard errors of those variables. It does, but it does not much affect the magnitude of the coefficients; equation (6) demonstrates that the policy regime variables are not simply picking up a secular decline in foundings.

In the seventh equation we introduce four variables representing key periods in American economic history, marked by wars and depressions. We omit the first period. In a model not reported here, without the time trend, several of these periods show significant effects. With the time trend, these periods show no significant effects. This supports our contention that key policy shifts, and not simply wider shifts in the economy, shaped the pattern of foundings.

Finally, in results not reported here, we tested for autocorrelation by adding the variable lagged foundings to each of the models in which it was not already present. When added to equation (2), the variable showed strong, positive, effects. When added to equations (4) through (7), it did not produce significant effects, although it did render lagged failures insignificant in equation (4) and both density terms insignificant in equation (6). Autocorrelation is not a significant problem in the equations that include the policy periods.

The results support hypotheses 1 , about public capitalization, 2 , about public bonds marketed in London, 3, about pro-cartel policies, 4, about antitrust, 6, about density-dependent legitimation and competition, and $8 a$, about the policy of encouraging entrepreneurs to buy failed lines. That density-dependent legitimation and competition influence foundings in this highly regulated industry is clear. Equally clear is that public policy shapes competition in important ways. The effects of density only appear when policy regimes are controlled.

\section{CONCLUSION}

How does policy shape competition? It establishes the ground rules of economic life, thereby creating markets. 
Without government monetary systems, legal frameworks for incorporation, and laws governing exchange, the world would have not markets as such. Far from having uninteresting, residual effects, as ecologists and industrial organization theorists are wont to argue, policy provides the framework for economic behavior. History has produced few natural laboratories for examining the effects of policy on industries, however, because nations rarely remodel industrial policies. The exception is nineteenth-century America, which witnessed three successive approaches to governing railroads: state capitalization, pro-cartel policies, and antitrust policies. Each produced a different sort of market, with its own patterns of economic behavior (White, 1988; Zelizer, 1988). These policy regimes are of substantial historical importance, both because the American economy industrialized under them and because they capture most cross-national variance today. Pro-cartel policies are now rare in American industry, but they remain common abroad. Antitrust policy governs most U. S. industries today and is now used in other developed countries. Public capitalization of growth industries remains common in Europe and America, although in America it has gone undercover. After supporting with great fanfare early agriculture, transportation, and banking. American governments backed more surreptitiously the auto and oil industries, via highway and mineral rights subsidies, and the aeronautics and electronics industries, via research and acquisition subsidies (Graham, 1991).

Analyses of the founding pattern of 317 Massachusetts railroads between 1826 and 1922 show the consequences of different policy regimes. Public capitalization policies increased the pool of resources available for building railroads and thus stimulated foundings. Pro-cartel policies mitigated price competition among incumbents and thus boosted foundings. Antitrust policy enlivened competition and thus discouraged foundings, although industry revenues and track mileage continued to grow. After antitrust, expansion occurred through the growth of incumbents rather than through the establishment of new railroads.

Other policies mattered as well. The policy of designing public bonds for sale in London led Massachusetts railraad foundings to follow the vicissitudes of the British economy, rather than the American economy. The policy of encouraging new operators to take over failed lines led to a quite direct relationship between failures in one year and foundings in the next.

In our analyses, public policies were so important that key ecological factors, density-dependent legitimation and competition, only showed effects after we controlled for policy shifts. Under stable capitalization and competition policies, our findings suggest, population dynamics operate as ecologists expect. Because most industries have operated under stable policies, important effects of policy are normally unseen. For instance, we would expect the pro-cartel regime that governed British railroading between 1825 and the First World War to boost the overall level of foundings, but, without a baseline, we would expect the effect to be difficult to 


\section{Railroad Foundings}

detect in time-series data. Under that stable policy regime, however, we would expect to find effects of density-dependent legitimation and competition.

We expect the effects we have found to be generalizable, but not because policy overly determines business strategy. Far from it. Railroaders actively constructed strategic responses to each policy shift, as we show in a companion piece to this article (Dowd and Dobbin 1998). After each policy shift they experimented broadly, eventually constructing one strategy as optimal. Under public capitalization policies, the consensus strategy was to found railroads wherever possible. Under rate regulation and pro-cartel policies, the consensus strategy was to found railroads to serve new markets. Under antitrust policy, the consensus strategy was to avoid founding new firms and concentrate resources in large enterprises. Under each regime, railroaders might have constructed a different strategy as optimal, but the strategies they did construct have since been copied and refined in other industries. We expect our findings to be generalizable because strategy prescriptions have become highly institutionalized. When new industries are brought under procartel or antitrust policies, they often follow prescriptions pioneered in railroading.

The lack of attention in sociology and economics to the role public policy plays in shaping business may be explained by a strong rhetoric of laissez faire in the principal exemplar nations for theory and research, Britain and the United States (Hamilton and Sutton, 1989; Lindberg and Campbell, 1991). That rhetoric contributed to a common-sense view of the economy, spelled out in 1776 in Adam Smith's The Wealth of Nations (1970), in which public policy follows wider economic laws. Smith implied that nations would prosper when they divined universal economic principles and devised compatible policies. Policies that coincided with growth came to be seen as reinforcing, rather than as constituting, economic laws. Even such dramatic policy innovations as antitrust came to be constructed, in the common-sense and scholarly rhetoric alike, as "nonintervention."

We have described the effects of three common policy regimes on industry competition and entrepreneurial behavior Our results support the notion that public policy creates the competitive environment firms operate in. Empirical studies of other industries are needed to specify these findings further. Do pro-cartel and antitrust policies matter most, as others suggest (Tirole 1988), in industries with high fixed costs that are prone to price wars? Does public capitalization affect foundings primarily, as other suggest (Harley, 1982), in sectors developed ahead of demand? Empirical studies of other aspects of industry regulation are also needed. Does the passage of general incorporation laws, obviating the need for special charters, enliven competition? Do protections from creditors spelled out in modern bankruptcy law increase risk taking among firms? The scope of our findings, and the effects of other policies that govern corporate form, financial markets, and competition among firms, remain to be explored in studies that span time and space. 


\section{REFERENCES}

Adams, Charles Frances, Jr.

1893 Railroads: Their Origins and Problems, rev. ed. New York: Putnam.

Amburgey, Terry L., Tina Dacin, and Dawn Kelly

1994 "Disruptive selection and population segmentation: Interpopulation competition as a segregating process." In Joel A. C. Baum and Jitendra $V$. Singh (eds.), Evolutionary Dynamics of Organizations: 240254. New York: Oxford University Press.

Atack, Jeremy, and Peter Passell

1994 A New Economic View of American History from Colonial Times to 1940, 2d ed. New York: W. W. Norton.

Bain, Joe $\mathrm{S}$.

1956 Barriers to New Competition. Cambridge, MA: Harvard University Press.

Barnett, William P., and Terry

Amburgey

1990 "Do larger organizations generate stronger competition?" In Jitendra Singh (ed.). Organizational Evolution: New Directions: 78-102. Newbury Park CA: Sage

Barnett, William P., and Glenn R. Carroll

1987 "Competition and mutualism among early telephone companies." Administrative Science Quarterly, 32: 400-421.

1993 "How institutional constraints affected the organization of early American telephony." Journal of Law, Economics, and Organization, 9: 98-126.

Barron, David N.

1992 "The analysis of count data: Overdispersion and autocorrelation." In Peter Marsden (ed.), Sociological Methodology, 22: 179-220. San Francisco: Jossey-Bass

Baum, Joel A. C.

1998 "Organizational ecology." In Stewart R. Clegg, Cynthia Hardy, and Walter Nord (eds.) Handbook of Organization Studies. London: Sage (forthcoming).

Baum, Joel A. C., and Christine Oliver

1992 "Institutional embedcedness and the dynamics of organizational populations." American Sociological Review, 57: 540560 .
Berk, Gerald

1994 Alternative Tracks: The Constitution of American Industrial Order, 1865-1917. Baltimore Johns Hopkins University Press.

Binder, John J.

1988 "The Sherman Antitrust Act and the railroad cartels." Jour nal of Law and Economics, 31: 443-468

Bittlingmayer, George

1985 "Did antitrust policy cause the great merger wave?" Journal of Law and Economics, 77: $1-32$.

Bruchey, Stuart

1990 Enterprise: The Dynamic Economy of a Free People. Cambridge, MA: Harvard University Press.

Callender. G. S.

1902 "The early transportation and banking enterprises of the states in relation to the growth of corporations." Quarterly Journal of Economics, 17: 111-162.

Cameron, A. Colin, and Pravin K. Trivedi

1986 "Econometric models based on count data: Comparisons and applications of estimators and tests." Journal of Applied Econometrics, 1:29-53.

Campbell, John L., J. Rogers Hollingsworth, and Leon N.

Lindberg (eds.)

1991 Governance of the American Economy. New York: Cambridge University Press.

Carroll, Glenn R.

1985 "Organizational ecology." In Annual Review of Sociology, 10: 71-93. Palo Alto, CA: Annual Reviews

Carroll, Glenn R., and Michael T. Hannan

1995 "Resource partitioning." In Glenn R. Carroll and Michael T. Hannan (eds.), Organizations in Industry: 215-221. New York: Oxford University Press.

Carroll, Glenn R., and Yangchung Paul Huo

1986 "Organizational and institutional environments in ecological perspective: Findings from the local newspaper industry.' American Journal of Sociology, 91: 838-873.
Carter, Susan B., and Richard Sutch

1992 "The Great Depression of the 1890s: New suggestive estimates of the unemployment rate, 1890-1905." Research in Economic History, 14: 347376

Chandler, Alfred D., Jr. (ed.)

1965 Railroads: The Nation's First Big Business. New York: Harcourt, Brace, and World

Chandler, Alfred D., Jr.

1977 The Visible Hand: The Managerial Revolution in American Business. Cambridge, MA: Harvard University Press.

1990 Scale and Scope. Cambridge, MA: Harvard University Press.

Cleveland-Stevens, Edward

1915 English Railways: Their Development and Their Relation to the State. London: George Routledge and Sons.

Cleveland, Frederick, and Fred Powell

1909 Railroad Promotion and Capitalization in the United States. New York: Longmans, Green.

Coase, R. H.

1988 The Firm, the Market and the Law. Chicago: University of Chicago Press.

Cochran, Thomas C

1965 Railroad Leaders 1845-1890: The Business Mind in Action. New York: Russell \& Russell

Davis, Gerald F., Kristina A.

Diekmann, and Catherine $\mathrm{H}$.

Tinsley

1994 "The decline and fall of the conglomerate firm in the 1980s: The deinstitutionalization of an organizational form." American Sociological Review, 59: 547-570.

Delacroix, Jacques, and Glenn R. Carroll

1983 "Organizational foundings: An ecological study of the newspaper industries of Argentina and Ireland." Administrative Science Quarterly, 28: $274-$ 291

Delacroix, Jacques, and Hayagreeva Rao

1994 "Externalities and ecological theory: Unbundling density dependence." In Joel A. C. Baum and Jitendra $V$. Singh (eds.), Evolutionary Dynamics of Organizations: $255-268$. New York: Oxford University Press. 
Railroad Foundings

Delacroix, Jacques, and Michael E. Solt

1988 "Niche formation and foundings in the California wine industry." In Glenn R. Carroll (ed.), Ecological Models of Organizations: 53-70. Cambridge, MA: Ballinger.

DiMaggio, Paul J., and Walter W. Powell

1983 "The iron cage revisited: Institutional isomorphism and collective rationality in organizational fields." American Sociological Review, 35: 147160.

1991 "Introduction." In Walter W. Powell and Paul J. DiMaggio (eds), The New Institutionalism in Organizational Analysis: 1-40. Chicago: University of Chicago Press.

Dobbin, Frank

1994 Forging Industrial Policy: The United States, Britain, and France in the Railway Age. Cambridge: Cambridge University Press.

Dobbin, Frank, John Sutton, John W. Meyer, and W. R. Scott

1993 "Equal opportunity aw and the construction of interna labor markets." American Journal of Sociology, 99: 396427.

Doukas, Kimon A

1945 The French Railroads and the State. New York: Columbia University Press.

Dowd, Timothy, and Frank Dobbin 1998 "Was there a market before antitrust?: Railroads and regulation in America." n Joseph Porac and Marc Ventresca (eds.), Constructing Markets and Industries. New York: Pergamon (forthcoming).

Dunlavy, Colleen

1991 "Mirror images: Political structure and early railroad policy in the United States and Prussia." Studies in American Political Development, 5: 1-35.

1993 Politics and Industrialization: Early Railroads in tre United States and Prussia. Princeton: Princeton University Press.

\section{Edelman, Lauren}

1990 " Legal environments and organizational governance: The expansion of due process in the American workplace." American Journal of Sociology, 95: 1401-1440.

1992 "Legal ambiguity and symbolic structures: Organizational mediation of civil rights law." American Journal of Sociology, 97: 1531-1576.
Fink, Albert

1979 "Argument before the Committee of Commerce of the House of Representatives of the United States on the Rea gan bill for the regulation of interstate commerce." In Alfred D. Chandler (ed.), The Railroads: Pioneers in Modern Management: 3-55. New York: Arno.

Fisher, Charles E.

1947 Whistler's Railroad: The Western Railroad of Massachusetts. Bulletin No. 69. Boston: Railway and Locomotive Historical Society.

\section{Fishlow, Albert}

1966 "Productivity and technological change in the railroad sector, 1840-1910." In Dorothy S. Brady (ed.). Output, Employment, and Productivity in the United States after 1800: 583-646. New York: National Bureau of Economic Research.

\section{Fligstein, Neil}

1990 The Transformation of Corporate Control. Cambridge. MA: Harvard University Press.

1996 "Markets as politics: A political-cultural approach to market institutions." American Sociological Review, 61: 656-674.

Florence, P. Sargent

1953 The Logic of British and American Industry: A Realistic Analysis of Economic Structure and Government. London: Routledge and Kegan Paul.

Freeman, John, and Alessandro Lomi

1994 "Resource partitioning and foundings of banking cooperatives in Italy." In Joel A. C. Baum and Jitendra $V$. Singh (eds.), Evolutionary Dynamics of Organizations: 269-293. New York: Oxford University Press

Goodrich, Carter

1960 Government Promotion of American Canals and Railroads 1800-1890. New York: Columbia University Press.

1968 "State in, state out-A pattern of development policy." Journal of Economic Issues, 30: 365-383.

Graham, Otis L., Jr.

1991 Losing Time: The Industrial Policy Debate. Cambridge. MA: Harvard University Press
Granovetter, Mark

1985 Economic Action and Social Structure: The Problem of Embeddedness. American Journal of Sociology, 91: 481-510

Greene, William H.

1990 LIMDEP Version 5.1 Manual New York: Econometric Software, Inc.

Hamilton, Gary G., and John R. Sutton

1989 "The problem of control in the weak state: Domination in the United States, 1880-1920."

Theory and Society, 18: 1-46.

Handlin, Oscar, and Mary F.

Handlin

1947 Commonwealth: A Study of the Role of Government in the American Economy: Massachusetts, 1774-1861. Cambridge, MA: Harvard University Press

Hannan, Michael T., and Glenn R. Carroll

1992 Dynamics of Organizational Populations: Density, Legitimation, and Competition. New York: Oxford University Press.

1995 "Theory building and cheap talk about legitimation: Reply to Baum and Powell." American Sociological Review, 60: 539-544

Hannan, Michael T., and John Freeman

1987 "The ecology of organizational founding rates: The dynamics of foundings of American labor unions, 1836-1975." American Journal of Sociology, 92: 910-943.

1989 Organizational Ecology. Cambridge, MA: Harvard University Press

Harley, C. Knick

1982 "Oligopoly agreement and the timing of American railroad construction." Journal of Economic History, 42: 797-823.

Hartz, Louis

1948 Economic Policy and Democratic Thought: Pennsylvania, 1776-1860. Cambridge, MA: Harvard University Press.

Haveman, Heather A.

1994 "Follow the leader: Mimetic isomorphism and entry into new markets." Administrative Science Quarterly, 38: 593627

Hayward, Jack

1986 The State and the Market Economy: Industrial Patriotism and Economic Intervention in France. New York: New York University Press 
Henry, Robert S.

1945 "The American land grant legend in American history texts." Mississippi Valley Historical Review, 32: 171-194.

Heydinger, Earl L.

1954 "The English influence on American railroads." Railway and Locomotive History Bulletin. 91: 7-45.

Hilton, George W.

1966 "The consistency of the Interstate Commerce Act." Journal of Law and Economics, 19: 87-113.

Hollingsworth, J. Rogers

1991 "The logic of coordinating American manufacturing sectors." In John L. Campbell, J. Rogers Hollingsworth, and Leon N. Lindberg (eds.), Governance of the American Economy: 35-74. New York Cambridge University Press.

Johnson, Chalmers

$1982 \mathrm{MITI}$ and the Japanese Miracle: The Growth of Industrial Policy, 1925-1975. Stanford, CA: Stanford University Press.

Kennedy, Charles J.

1961 "The influence of government regulation on the management decisions of forty-five New England railroads, $1830-$ 1900 ." Railway and Local Historical Society Bulletin, 105: 6-22.

Kennedy, Robert Dawson, Jr.

1991 "The statist evolution of rail governance in the United States, 1830-1986." In John L. Campbell, J. Rogers Hollingsworth, and Leon N. Lindberg (eds.), Governance of the American Economy: 138-181. New York: Cambridge University Press.

Kirkland, Edward C.

1948 Men, Cities, and Transportation: A Study in New England History 1820-1900, 2 vols. Cambridge, MA: Harvard University Press.

Kolko, Gabriel

1965 Railroads and Regulation 1877-1916. Princeton: Princeton University Press.

Lindberg, Leon, and John L.

Campbell

1991 "The state and the organization of economic activity." In John L. Campbell, J. Rogers Hollingsworth, and Leon $N$. Lindberg (eds.), Governance of the American Economy 356-395. New York: Cambridge University Press.
Lindberg, Leon N., John L.

Campbell, and J. Rogers

Hollingsworth

1991 "Economic governance and the analysis of structural shange in the American economy." In John L. Campbell, J. Rogers Hollingsworth, and Leon N. Lindberg (eds.), Governance of the American Economy: 3-34. New York: Cambridge University Press

Lipset, Seymour Martin

1963 The First New Nation: The United States in Historical and Comparative Perspective. New York: Norton.

Locklin, David

1954 Economics of Transportation. 4th ed. Homewood, IL: Irwin.

MacAvoy, Paul $W$.

1965 The Economic Effects of Regulation: The Trunk Line Cartels and the Interstate Commerce Commission before 1900. Cambridge. MA: MIT Press.

Massachusetts, Board of Railroad Commissioners

1869-

1922 Anrual Report of the Railroad Commissioners. Boston: Commonwealth of Massachusetts.

Massachusetts, Committee on Railways and Canals

1838-

1856 Annual Report of the Raitroad Corporations of Massachusetts. Boston: Commonwealth of Massachusetts.

Massachusetts, General Court of 1825-

1922 Acts and Resolves of the General Court of Massachusetts. Boston: State Printers.

Massachusetts, Secretary of the Commonwealth

$1857-$

1869 Returns of the Railroad Corporations of Massachusetts. Boston: Commonwealth of Massachusetts.

McCraw, Thomas $\mathrm{K}$.

1984 Prophets of Regulation. Cambridge, MA: Harvard University Press.

McCullagh, P., and J. A. Nelder

1989 Generalized Linear Models, 2d ed. London: Chapman and Hall.

Meyer, John W.

1994 "Rationalized environments." In W. Richard Scott and John W. Meyer (eds.), Institutional Environments and Organizations: Essays and Studies: 2854. Newbury Park, CA: Sage.
Meyer, John W., and Brian Rowan

1977 "Institutionalized organizations: Formal structure as myth and ceremony." American Journal of Sociology, 83: 340-363

Mezias, Stephen J.

1990 "An institutional model of organizational practice: Financial reporting at the Fortune 500." Administrative Science Quarterly, 35: 431-457.

Parris, Henry

1965 Government and the Railways in Nineteenth Century Britain. London: Royal Institute of Public Administration.

Peterson, Trond, and Kenneth W. Koput

1991 "Density dependence in organizational mortality: Legitimacy or unobserved heterogeneity." American Sociological Review, 56: $399-409$

Poor, Henry $V$.

1860 History of the Railroads and Canals of the United States of America, Exhibiting Their Progress, Cost. Revenues Expenditures and Present Condition. New York: John H Schultz.

Ranger-Moore, James, Jane Banaszak-Holl, and Michael T. Hannan

1991 "Density-dependent dynamics in regulated industries: Founding rates of banks and life insurance companies." Administrative Science Quarterly, 36: 36-65

Ripley, William Z.

1915 Railroads, Finance and Organization. New York: Longmans, Green

Roy, William G.

1997 Socializing Capital: The Rise of the Large Industrial Corporation in America. Princeton, NJ: Princeton University Press.

Sanders, M. Elizabeth

1981 The Regulation of Natural Gas: Policy and Politics. 1938-1981. Philadelphia: Temple University Press.

Scheiber, Harry $N$.

1981 "Regulation, property rights, and definition of 'the market' Law and the American economy." Journal of Economic History, 41: 103-109. 
Schneiberg, Marc, and J. Rogers Hollingsworth

1989 "Transaction cost economics and trade associations." In Masahiko Aoki, Bo Gustafsson, and Oliver Williamson (eds.). The Firm as a Nexus of Treaties: 320-346. Newbury Park, CA: Sage.

Scott, W. Richard

1995 Institutions and Organizations. Thousand Oaks, CA: Sage.

Shepherd, William G.

1979 The Economics of Industrial Organization. Englewood Cliffs, NJ: Prentice-Hall.

Shonfield, Alfred

1965 Modern Capitalism. London: Oxford University Press.

Simmons, Jack

1978 The Railway in England and Wales 1830-1914. Leicester: Leicester University Press.

Singh, Jitendra V., David J.

Tucker, and Agnes G. Meinhard

1991 "Institutional change and ecological dynamics." In Paul J. DiMaggio and Walter W. Powell (eds.). The New Institutionalism in Organizational Analysis: 390-422. Chicago: University of Chicago Press.

Skowronek, Stephen

1982 Building a New American State: The Expansion of $\mathrm{Na}$ tional Administrative Capacities: 1877-1920. New York: Cambridge University Press.

Smith, Adam

1970 The Wealth of Nations, reprint ed. Baltimore: Penguin.

Stackelberg, Heinrich

1952 The Theory of the Market Economy. New York: Oxford University Press.

Stigler, George

1968 The Organization of Industry. Homewood, L: Irwin.

\section{Strang, David}

1994 "Institutional accounts of organizations as a form of structural analysis." In 3 . David Knottnerus and Christopher Prendergast (eds.), Current Perspectives in Social Theory: 151-174. Greenwich, CT: JAI Press.

\section{Railroad Foundings}

Strang, David, and John W.

Meyer

1993 "Institutional conditions for diffusion." Theory and Society, 22: 487-511

Strang, David, and Tanya

Uden-Holman

1998 "We have met the enemy: Institutional conditions for the founding of health maintenance organizations, 1971. 1982." In Samuel Bacharach (ed.). Research in the Sociology of Organizations, vol. 16. Greenwich, CT: JAl Press (forthcoming).

Sutton, John, and Frank Dobbin

1996 "The two faces of governance: Responses to legal uncertainty in American firms, 1955-1985." American Sociological Review, 61: 794-811.

Thompson, Margaret Susan

1983 "Corruption-or confusion? Lobbying and congressional government in the early gilded age." Congress and the Presidency, 10: 169-192.

Thorp, Willard Long

1926 Business Annals. New York: National Bureau of Economic Research.

Tirole, Jean

1988 The Theory of Industrial Organization. Cambridge, MA: MIT Press.

Tocqueville, Alexis de

1945 Democracy in America, reprint ed. Henry Reeve and Phillips Bradley, trans. New York: Vintage.

Tucker, David J., Jitendra V. Singh, and Agnes G. Meinhard 1990 "Organizational form, population dynamics, and institutional change: The founding patterns of voluntary organizations." Academy of Management Journal, 33: 151-178.
White, Harrison C.

1981 "Where do markets come from?" American Journal of Sociology, 87: 517-547

1988 "Varieties of markets." In Barry Wellman and Stephen D. Berkowitz (eds.), Social Structures: A Network Approach: 226-260. New York Cambridge University Press.

Wholey, Douglas R., John B.

Christianson, and Susan $M$.

Sanchez

1992 "Organizational size and failure among health maintenance organizations." American Sociological Review, 57: 829-842.

Wilcox, Clair

1960 Public Policies Toward Business, rev. ed. Homewood, IL. Irwin.

Willis, H. Parker, and Jules I.

Bogen

1936 Investment Banking, rev. ed. New York: Harper.

Zelizer, Viviana A.

1988 "Beyond the polemics on the market: Establishing a theoretical and empirical agenda." Sociological Forum, 4: 614634

Zucker, Lynne G.

1989 "Combining institutional theory and population ecology: No legitimacy, no history." American Sociological Review, 31: 542-545. 